\title{
PEMBERIAN EMOLIEN MINYAK ZAITUN DALAM MENURUNKAN SKALA PRURITUS PADA PASIEN HEMODIALISIS
}

\author{
Rizki Muliani' ${ }^{1}$, Syifa Asih Lestari², Nur Intan HHK ${ }^{3}$ \\ ${ }^{1,2,3}$ Fakultas Keperawatan Universitas Bhakti Kencana \\ rizki.muliani@bku.ac.id
}

\begin{abstract}
ABSTRAK
Toksik uremia dan hemodialisis sebagai penatalaksanaan Penyakit Ginjal Kronis (PGK) dapat menimbulkan pruritus. Pruritus mengakibatkan luka pada kulit, infeksi dan mengganggu kenyamanan pasien sehingga dibutuhkan terapi topikal tambahan oleh pasien. Minyak zaitun merupakan salah satu jenis emolien topikal yang alami, tidak ada efek samping dan mudah didapat tanpa resep dokter. Tujuan penelitian ini untuk mengetahui pengaruh pemberian emolien minyak zaitun terhadap skala pruritus pada pasien yang menjalani hemodialisis. Jenis penelitian menggunakan preeksperimen dengan pendekatan one group pre-post-test design. Sampel dalam penelitian ini sebanyak 23 pasien yang diambil dengan teknik purposive sampling. Instrumen yang digunakan yaitu Numerical Rating Scale (NRS) pruritus dan prosedur pemberian minyak zaitun. Analisis data menggunakan uji $t$-test sampel berpasangan. Hasil penelitian menunjukkan 30,4\% (7 orang) mengalami pruritus dengan skala 7 sebelum diberikan emolien minyak zaitun dan didapatkan 34,8\% (8 orang) mengalami pruritus dengan skala 3 setelah diberikan emolien minyak zaitun. Hasil analisis $t$-test didapat $p$-value $=0,000$ sehingga disimpulkan ada pengaruh pemberian emolien minyak zaitun terhadap skala pruritus pada pasien yang menjalani hemodialisis. Penurunan skor pruritus setelah diberikan minyak zaitun karena minyak zaitun mengisi ruang keratin kulit sehingga melembabkan, mencegah kulit gatal, mengobati luka dan infeksi. Oleh karena itu, perlu dilakukan terapi tambahan berupa penggunaan minyak zaitun untuk mengatasi pruritus pada pasien PGK.
\end{abstract}

Kata kunci : hemodialisis, minyak zaitun, pruritus

\section{GIVING OLIVE OIL EMOLLIENTS TO REDUCE PRURITUS SCALE IN PATIENTS UNDERGOING HEMODIALYSIS}

\section{ABSTRACT}

Toxic uremia and hemodialisis as management of CKD can cause pruritus. Pruritus causes skin injury, infection and disturbs patient comfort, so additional topical therapy is needed. Olive oil is a natural topical emollient, has no side effects, and is readily available without a doctor's prescription. This study aimed to determine the effect of olive oil on the pruritus scale in patients undergoing hemodialysis. This type of research used a pre-experiment with a one-group pre-post test design approach. The sample in this study was 23 patients who take by purposive sampling technique. The instruments used were NRS pruritus and the procedure for administering olive oil. Data analysis used paired sample t-test. The results showed that $30.4 \%$ had pruritus on a scale of 7 before being given olive oil, and $34.8 \%$ had pruritus on a scale of 3 after being given olive oil. The results of the t-test analysis obtained $p$-value $=0.000$, so it concluded that there was an effect of olive oil on the pruritus scale in patients undergoing hemodialysis. The pruritus score decreased after being given olive oil because olive oil fills the keratin space of the 
skin so that it moisturizes, prevents itchy skin, treats wounds and infections. Therefore it is necessary to do additional therapy in olive oil to treat pruritus in CKD patients.

Keywords: hemodialysis, kidney disease, olive oil, pruritus

\section{PENDAHULUAN}

Ginjal merupakan organ yang sangat penting dalam pengaturan cairan asam basa, metabolisme, pembuangan racun dan sampah dari dalam tubuh. Namun, jika terjadi kerusakan dapat mengakibatkan ginjal gagal dalam menjalankan fungsinya, dan jika dibiarkan dapat terjadi penyakit ginjal kronis (PGK). PGK ini menyebabkan ginjal tidak mampu mempertahankan metabolisme dan keseimbangan cairan dan elektrolit sehingga mengakibatkan uremia (Black et al, 2014). Penumpukan uremia ini dapat ditangani dengan melakukan dialisis yang salah satunya dilakukan melalui hemodialisis yang menjadi pilihan utama dan metode perawatan umum untuk penderita penyakit ginjal kronik.

Jumlah tindakan hemodialisis di Indonesia sebanyak 2.754.409 tindakan, kontribusi cukup besar dimiliki oleh provinsi Jawa Barat dengan jumlah penderita aktif sebanyak 33.828 orang dan pasien baru 14.771 orang (Indonesia Renal Registry, 2018). Pruritus uremia adalah komplikasi umum yang dialami pasien hemodialisis. Pruritus terjadi pada $15 \%$ $49 \%$ pasien PGK predialisis dan 50\%-90\% pada pasien yang menjalani dialisis (peritoneal dialisis dan hemodialisis) (Panahi et al., 2016) frequent and potentially disabling problem in chronic kidney disease (CKD. Penelitian pruritus jarang dilakukan dibanding dengan penelitian komplikasi hemodialisis yang lain seperti kelelahan. Pruritus pada pasien hemodialisis dapat terjadi karena kulit kering akibat penarikan cairan saat hemodialisis berlangsung, penumpukan kadar beta 2 microglobulin dalam darah, serta retensi dari vitamin A. Pruritus berat dapat menimbulkan xerosis linier yang khas pada kulit yang disertai perdarahan dan infeksi sehingga mengakibatkan gangguan aktivitas, mengganggu tidur dan juga menurunkan kualitas hidup. Kualitas hidup menurun karena menyebabkan ketidaknyamanan yang parah, kecemasan, depresi, dan gangguan tidur (Panahi et al., 2016; frequent and potentially disabling problem in chronic kidney disease (CKD Kimata et al., 2014).

Oleh karena itu, perlu dilakukan penanganan untuk mengatasi pruritus pada pasien PGK. Untuk mengurangi keluhan pruritus pada pasien PGK yakni dapat menggunakan GLAEnchrised cream, mengoptimalkan dosis dialisis, capsaicin topikal, dan emolien (Simonsen et al., 2017). Dalam penelitian Shirazian et al (2017) sebelumnya disarankan mencoba melakukan perawatan pruritus dengan menggunakan emolien sehingga dalam penelitian ini peneliti mencoba menggunakan emolien Olive Oil (minyak zaitun) dengan alasan mudah didapat dan bukan barang yang asing buat orang Indonesia.

Minyak zaitun adalah minyak yang diperoleh dari perasan buah Olea europaea. Minyak zaitun mengandung berbagai asam lemak, vitamin, terutama sumber vitamin $\mathrm{E}$ yang berfungsi sebagai anti oksidan alami yang membantu melindungi struktur sel yang penting terutama membran sel dari kerusakan akibat adanya radikal bebas, juga berperan sangat penting bagi kesehatan kulit, yaitu dengan menjaga, meningkatkan elastisitas dan kelembapan kulit, mencegah proses penuaan dini, melindungi kulit dari kerusakan akibat radiasi sinar ultraviolet, serta mempercepat proses penyembuhan luka (Fajriyah et al., 2015). Penelitian lain tentang manfaat zaitun juga membuktikan bahwa emoilen minyak zaitun 
efektif mengatasi kulit kering dan pruritus pada neurodermatitis dan juga mampu mempercepat penyembuhan luka (Shamim et al., 2004).

Penelitian ini merupakan lanjutan dari penelitian Shirazian et al (2017) sebelumnya yang menyarankan penggunaan emolien untuk penanganan pruritus. Penelitian Ariyani et al (2020) menyatakan bahwa ada perbedaan tingkat pruritus sebelum dan setelah pemberian olive oil pada pasien PGK di ruang hemodialisa RS dr. Soekardjo Tasikmalaya, tetapi dalam penelitian ini belum menggambarkan kondisi kulit yang mengalami pruritus sebelum dan setelah pemberian olive oil. Pada penelitian ini, peneliti akan melakukan penilaian skala pruritus pada pasien PGK dengan menggunakan Olive Oil (minyak zaitun).

Tujuan penelitian ini adalah untuk mengetahui skala puritus pada pasien PGK yang menjalani hemodialisis sebelum dan sesudah diberikan emolien olive oil serta mengetahui pengaruh pemberian emolien olive oil dapat mengatasi pruritus pada pasien PGK yang menjalani hemodialisis. Manfaat penelitian ini adalah untuk meningkatkan pelayanan asuhan keperawatan pada pasien PGK yang menjalani hemodialisis.

\section{METODOLOGI}

Penelitian ini menggunakan penelitian preeksperimen dengan one group pre-posttest design. Populasi dalam penelitian ini adalah 168 pasien penyakit ginjal kronik yang menjalani hemodialisis di ruang hemodialisis RSUD Majalaya. Sampel dalam penelitian ini sebanyak 23 pasien yang diambil dengan menggunakan teknik purposive sampling yaitu pengambilan sampel yang didasari oleh suatu pertimbangan yang sesuai dengan kriteria inklusi (Notoatmodjo, 2013). Adapun kriteria inklusi dalam penelitian ini adalah pasien PGK dengan pruritus yang menjalani terapi hemodialisis di RSUD Majalaya secara teratur, rutin dan terjadwal, pasien yang telah menjalani hemodialisis minimal 6 bulan, pasien yang mengikuti kegiatan penelitian sesuai aturan dan waktu yang telah ditentukan.

Instrumen dalam penelitian ini adalah NRS untuk menilai skor pruritus pasien yang menjalani hemodialisis dan operasional prosedur pemberian minyak zaitun. Pengumpulan data dilakukan dengan menilai skor puritus pada pasien yang menjalani hemodialisis sebelum diberikan intervensi. Selanjutnya dilakukan intervensi berupa pemberian terapi topikal emoilen minyak zaitun sesuai prosedur yang telah ditentukan setelah pemasangan akses hemodialisis dilakukan. Peneliti melakukan dan mengajarkan cara memakai minyak zaitun yakni mengoleskan secara merata pada permukaan kulit yang mengalami gatal dan kering dengan tehnik memutar atau mengusap satu arah. Pemakaian minyak zaitun ini dilakukan 2x sehari (07:00 pagi dan 07:00 malam), untuk pemakaian yang kedua, peneliti menganjurkan pasien untuk melakukan di rumah sesuai yang telah diajarkan. Sebagai pemantauan dan mencegah terjadinya bias, peneliti membuat kontrak dengan keluarga pasien sebagai pengingat dan pengawas pasien dalam melakukan pengolesan minyak zaitun di rumah. Peneliti juga melakukan komunikasi melalui media komunikasi (Handphone) sebagai pengingat dalam pemberian terapi minyak zaitun tersebut. Pelaksanaan terapi minyak zaitun ini dilakukan selama 4 minggu. Setelah empat minggu intervensi selanjutnya dilakukan posttest dengan mengukur kembali skala pruritus yang dialami pasien saat itu.

Selanjutnya dilakukan analisis dengan menggunakan rumus Uji T-test karena uji normalitas menggunakan Shapiro-Wilk didapatkan hasil 0,101 pada pre dan 0.027 pada post, karena $p$-value $>0,05$ dapat diartikan data berdistribusi normal.

Penelitian dilakukan di ruang hemodialisis 
RSUD Majalaya Kabupaten Bandung.

\section{HASIL}

Tabel 1. Skala Pruritus Sebelum Diberikan

Emolien Minyak Zaitun pada Pasien yang Menjalani Hemodialisis

\begin{tabular}{lcc}
\hline \multicolumn{1}{c}{ Skor } & n & $\mathbf{\%}$ \\
\hline $0=$ Tidak gatal & 0 & $0 \%$ \\
$1=$ Gatal sangat ringan & 0 & $0 \%$ \\
$2=$ Gatal tidak nyaman & 0 & $0 \%$ \\
$3=$ Gatal bisa ditoleransi & 3 & $13 \%$ \\
$4=$ Gatal mengganggu & 1 & $4,3 \%$ \\
$5=$ Gatal sangat mengganggu & 4 & $17,4 \%$ \\
$6=$ Gatal terus menerus & 4 & $17,4 \%$ \\
$7=$ Gatal lebih sering & 7 & $30,4 \%$ \\
$8=$ Sangat Gatal & 3 & $13 \%$ \\
$9=$ Gatal luar biasa & 1 & $4,3 \%$ \\
$10=$ Gatal tidak bisa bicara & 0 & $0 \%$ \\
\hline Total & $\mathbf{2 3}$ & $\mathbf{1 0 0} \%$ \\
\hline
\end{tabular}

Berdasarkan tabel di atas diketahui bahwa hampir setengahnya pasien sebanyak 30,4 \% (7 orang) mengalami gatal pada skor 7 atau gatal lebih sering sebelum diberikan emolien minyak zaitun.

Tabel 2. Skala Pruritus Sesudah Diberikan Emolien Minyak Zaitun pada Pasien yang Menjalani Hemodialisis

\begin{tabular}{lcc}
\hline \multicolumn{1}{c}{ Skor } & n & \% \\
\hline $0=$ Tidak gatal & 0 & $0 \%$ \\
$1=$ Gatal sangat ringan & 1 & $4,3 \%$ \\
$2=$ Gatal tidak nyaman & 2 & $8,7 \%$ \\
$3=$ Gatal bisa ditoleransi & 8 & $34,8 \%$ \\
$4=$ Gatal mengganggu & 7 & $30,4 \%$ \\
$5=$ Gatal sangat mengganggu & 5 & $21,7 \%$ \\
$6=$ Gatal terus menerus & 0 & $0 \%$ \\
$7=$ Gatal lebih sering & 0 & $0 \%$ \\
$8=$ Sangat Gatal & 0 & $0 \%$ \\
$9=$ Gatal luar biasa & 0 & $0 \%$ \\
$10=$ Gatal tidak bisa bicara & 0 & $0 \%$ \\
\hline Total & $\mathbf{2 3}$ & $\mathbf{1 0 0} \%$ \\
\hline \multicolumn{1}{c}{ Berdasarkan tabel di } & atas & diketahui
\end{tabular}
bahwa hampir setengahnya pasien sebanyak 34,8 $\%$ (8 orang) mengalami gatal pada skor 3 atau gatal bisa ditoleransi setelah diberikan emolien minyak zaitun.

Tabel 3. Pengaruh Terapi Topikal Emoilen Minyak Zaitun terhadap Skala Pruritus pada Pasien yang Menjalani Hemodialisis

\begin{tabular}{ccccc}
\hline Variabel & $\mathbf{n}$ & Mean & Standar Deviasi & p-value \\
\hline Pre test & 23 & 6,04 & 1.692 & 0,000 \\
Post test & 23 & 3,57 & 1.080 & \\
\hline
\end{tabular}

Berdasarkan tabel di atas didapatkan nilai p-value $(0,000)$ dan karena hasil $p$ value $<0,05$ maka Ho ditolak dan Hi diterima sehingga dapat disimpulkan bahwa ada pengaruh pemberian emoilen minyak zaitun terhadap skala pruritus pada pasien yang menjalani hemodialisis.

\section{PEMBAHASAN}

1. Skala Pruritus Sebelum Diberikan Emolien Minyak Zaitun
Lebih dari $40 \%$ pasien yang menjalani hemodialisis menderita pruritus kronis; setengah dari mereka mengeluh tentang pruritus umum. Penyebab pruritus pada pasien PGK yang paling sering adalah toksik uremia. Patogenesis pruritus masih belum jelas, diduga parathormone, histamin, kalsium dan magnesium sebagai faktor patogenetik(Mettang \& Kremer, 2015). Selain itu penyakit penyerta seperti hiperparatiroid sekunder juga dapat memperberat keadaan 
pruritus karena penumpukan fosfat dalam kulit dan kulit kering akibat dari atropinya kelenjar sebasea. Keadaan pruritus juga dapat timbul dan lebih parah saat kulit berkeringat, udara panas dan pada malam hari (Harlim \& Yogyartono, 2012). Hal ini juga ditemukan dalam penelitian sebelumnya oleh Roswati (2013) di RSUP H. Adam Malik ditemukan $60-80 \%$ pasien yang mengalami dialisis mengalami pruritus dan Astuti et al (2017) juga menemukan $50,6 \%$ pasien mengalami pruritus sedang di RSUD Zainoel Abidin Banda Aceh.

Saat penelitian, pasien mengungkapkan bahwa gatal yang dirasakan sering menganggu aktivitas dan kualitas tidur mereka. Gatal dirasakan di area punggung, kaki dan tangan. Selain itu, gatal juga menyebabkan kulit lecet hingga berdarah. Saat dikaji sebagian besar keadaan kulit pasien mengalami kering. Keadaan kulit pada 30,4 \% (7 orang) yang mengalami gatal pada skor 7 tampak lebih kering, terdapat luka pada kaki dan tangan akibat garukan, sedangkan pada $13 \%$ (3 orang) yang mengalami gatal pada skor 8 terjadi luka akibat garukan lebih luas yakni pada kaki, tangan dan punggung. Selanjutnya pada 4,3 $\%$ (1 orang) yang mengalami gatal pada skor 9 selain luka akibat garukan yang cukup banyak. Gatal juga menyebabkan keadaan psikis pasien terganggu ditandai dengan ungkapan pasien yang jengkel terhadap gatalnya dan terlihat marah-marah, keluarga juga mengatakan akibat gatal-gatalnya pasien sering terganggu tidurnya dan marah-marah. Menurut Pardede (2016) Pruritus uremik adalah pruritus yang terjadi pada gagal ginjal yang disebabkan oleh toksin uremik, dengan prevalensi berkisar antara 20\%$50 \%$. Pruritus dapat bersifat menyeluruh atau local dengan intensitas dan distribusi pruritus bervariasi dengan derajat keparahan bergantung pada beratnya. Intensitas pruritus mulai dari yang ringan yang timbul sporadik sampai dengan yang berat hingga tidak dapat istirahat baik siang maupun malam hari. Pruritus uremik ini dapat mengganggu aktivitas atau pekerjaan, mengganggu tidur, dan menurunkan kualitas hidup. Penurunan kualitas hidup pasien akibat dari pruritus juga ditemukan pada penelitian di Jepang oleh Kimata et al (2014) yang menemukan $44 \%$ dari 6.480 pasien penyakit ginjal kronis mengalami pruritus dan rendahnya kualitas hidup. Li et al (2015)362 CAPD cases were investigated from January 2012 to April 2013. Pruritus was assessed by visual analogue scale. Results The prevalence of severe pruritus and mild to moderate pruritus was $12.7 \%$ and $52.5 \%$, respectively. The patients with severe pruritus had the longest duration of $\mathrm{PD}(\mathrm{p}<0.001$ juga menemukan $52,5 \%$ dari 362 pasien di China mengalami pruritus.

Pada pretest ditemukan 13\% (3 orang) yang mengalami pruritus pada skala 3. Saat dilakukan wawancara pasien mengungkapkan gatal yang dirasakan jarang dan merasa sudaah terbiasa dengan rasa gatalnya karena sudah lama mengalami keluhan tersebut. Saat dikaji lama menderita penyakit ginjal kronik dan menjalani hemodialisis satu orang 8 tahun, 6 tahun dan satu orang lainnya 7 bulan. Dengan lamanya mengalami keluhan gatal dan gangguan lainnya akibat penyakit ginjal kronis ini, persepsi pasien pada rasa gatal sudah terbiasa dan merasa tidak asing dengan keluhannya sedangkan pada pasien yang baru menjalani penyakit ginjal kronis selama 7 bulan ini dapat disebabkan karena efek hemodialisis yang menyebabkan pruritus belum timbul atau karena tingkat toksik uremia yang 
rendah.

Untuk mengatasi rasa gatalnya responden mengatakan diberikan salep dan obat gatal apabila responden meminta resep kepada dokter atau melakukan kunjungan ke Rawat jalan Poli Kulit. Beberapa pasien merasa sudah bosan menggunakan obat oral untuk mengatasi rasa gatalnya dan meminum obat secara tidak teratur karena merasa keluhan gatalnya yang tidak sembuhsembuh, hal ini sesuai dengan tingginya skor gatal yang dialami oleh hampir setengah dari jumlah responden. Di ruangan, tindakan perawat yang diberikan pada pasien yang mengalami gatal hanya mengoptimalkan dosis dialisis saja. Oleh karena itu, peneliti menganjurkan untuk melakukan terapi topikal minyak zaitun yang mudah didapat oleh responden sebagai terapi tambahan dan perawatan kulit.

2. Skala Pruritus Setelah Diberikan Emolien Minyak Zaitun

Setelah dilakukan intervensi pada pasien yang menjalani hemodialisis keadaan kulit pasien menjadi lebih lembab dan halus. Hampir setengah dari responden 34,8\% (8 orang) mengalami gatal pada skor 3 atau gatal bisa ditoleransi saat dilakukan observasi ditandai dengan pada kulit tidak terlihat garis-garis bekas garukan dan 30,4 \% (7 orang) mengalami gatal pada skor 4 atau gatal mengganggu ditandai dengan adanya garisgaris pada kulit bekas garukan tanpa luka. Selanjutnya sebagian kecil dari responden $21,7 \%$ (5 orang) mengalami gatal pada skor 5 atau gatal sangat mengganggu ditandai dengan garis pada kulit bekas garukan lebih banyak yakni kaki dan punggung tanpa luka, 8,7\% (2 orang) mengalami gatal pada skor 2 ditandai dengan ungkapan pasien yang masih gatal pada malam hari tetapi tidak mengganggu tidur dan 4,3\% (1 orang) mengalami gatal pada skor 1 ditandai dengan ungkapan pasien yang gatalnya sudah jarang dirasakan. Hal ini sesuai dengan penelitian Pele \& Waluyo (2019) yang menunjukkan bahwa memandikan pasien dengan minyak zaitun dan air hangat memiliki efek menenangkan pada pasien dan mencegah kerusakan integritas kulit. Minyak zaitun berasal dari ekstraksi buah zaitun yang mengandung asam linoleate yaitu asam lemak esensial bagi manusia yang bermanfaat bagi kesehatan kulit dengan mengatasi masalah yang berkaitan dengan kulit bersisik, eksim, dan kulit kering. Minyak zaitun memiliki sifat yang keras untuk mengangkat sisa-sisa kulit mati namun lembut untuk kulit (Lin, Zhong, \& Santiago, 2017).

Mekanisme kerja emoilen yakni mengisi ruang keratinosit untuk membentuk permukaan yang halus dengan menggunakan bahan yang berminyak dan tidak larut dalam air dan meningkatkan kohesi dari sel-sel keratinosit (Lynde et al, 2012). Dengan kelembaban kulit yang baik keluhan pruritus akibat kulit kering dapat teratasi dan dapat menurunkan skala pruritus pada pasien. Penggunaan minyak zaitun dalam mengatasi pruritus pada pasien penyakit ginjal merupakan penelitian pertama sebagai tindak lanjut saran dari penelitian sebelumnya yang dilakukan (Shirazian et al., 2017) dan dapat dibuktikan bahwa penggunaan emoilen minyak zaitun ini mampu menurunkan skala pruritus pada pasien penyakit ginjal kronis. Pada penelitian sebelumnya banyak menggunakan jenis emoilen lain yang berupa salep atau golongan obat yang didapat harus dengan resep dokter, sehingga penggunaan minyak zaitun untuk mengatasi pruritus sangat efektif penggunaannya karena mudah didapat dan tanpa efek samping. 
Pada posttest intervensi minyak zaitun, ditemukan 21,7\%(5 orang) mengalami pruritus pada skor 5. Saat dikakukan observasi dan wawancara ditemukan keadaan kulit terdapat bekas garukan pada kaki dan punggung yang lebih banyak tanpa luka dan pasien mengungkapkan kurang menjaga asupan makanan. Hal ini dapat disebabkan karena toksik uremia yang tinggi karena asupan makanan yang tidak dijaga dan kondisi kulit yang sering berkeringat sehingga pengeluaran toksik uremia lewat keringat dapat menyebabkan kulit lebih gatal. Oleh karena itu, selain menjaga kelembaban kulit dengan menggunakan minyak zaitun, pasien juga perlu menjaga asupan makanan dan minuman yang dapat memicu peningkatan toksik uremia yang tinggi sehingga rasa gatal yang menganggu dapat berkurang dan teratasi.

3. Pengaruh Pemberian Emolien Minyak Zaitun Terhadap Skala Pruritus pada Pasien Penyakit Ginjal Kronis

Setelah dilakukan intervensi ditemukan penurunan skor pruritus, hal ini menunjukan adanya pengaruh pemberian emoilen minyak zaitun terhadap skala pruritus pada pasien penyakit ginjal kronik. Saat dilakukan wawancara, responden mengungkapkan bahwa rasa gatal dikulit berkurang dan keadaan kulit lebih lembab dari sebelumnya dan luka akibat garukan sembuh. Sejalan dengan penelitian Ariyani et al (2020) yang menunjukkan ada perbedaan tingkat pruritus pada pasien penyakit ginjal kronik yang menjalani hemodialisis setelah diberikan minyak zaitun. Penelitian Pele \& Waluyo (2019) juga membuktikan bahwa penggunaan minyak zaitun dapat mencegah resiko kerusakan integritas kulit pada pasien dengan penyakit kronik.
Hal ini mendukung teori dari manfaat minyak zaitun yang bermanfaat untuk penyembuhan gangguan yang terdapat pada kulit dengan meningkatkan kelembapan dan elastisitas kulit sehingga dapat menurunkan pruritus pada penderita penyakit ginjal kronik (Ichihashi et al., 2018). Minyak zaitun berasal dari ekstraksi buah zaitun. Minyak zaitun mengandung asam linoleat yang bermanfaat bagi kesehatan kulit dengan mengatasi masalah kulit bersisik, eksim, dan kulit kering (Lin et al., 2018). Penggunaan minyak zaitun dalam mengatasi pruritus pada pasien penyakit ginjal merupakan penelitian sebagai tindak lanjut saran dari penelitian sebelumnya (Shirazian et al., 2017) dan dapat dibuktikan bahwa penggunaan emoilen minyak zaitun ini mampu menurunkan skala pruritus pada pasien penyakit ginjal kronis.

$$
\text { Sejalan dengan penelitian }
$$

Setianingsih (2017); Sebayang \& Sembiring (2020) yang menyatakan ada pengaruh pemberian minyak zaitun terhadap kesembuhan ruam popok pada bayi usia 0-12 bulan. Minyak zaitun adalah sumber utama lemak yang mengandung emolion berfungsi untuk mencegah infeksi kulit, melembutkan, dan menjaga kekenyalan kulit.

Penelitian lain menunjukkan ada pengaruh minyak zaitu terhadap kerusakan integritas kulit pada pasien DM tipe II. Kerusakan integritas kulit gatal atau pruritus pada pasien DM tipe II disebabkan oleh mengeringnya kulit (gangguan pada regulasi tubuh) yang membuat kulit mudah luka dan gatal. Gatal menimbulkan sensasi yang tidak menyenangkan yang memicu keinginan untuk menggaruk, jika menggaruk dilakukan terus-menerus dapat mengakibatkan terjadinya inflamasi sel dan pelepasan histamin oleh ujung saraf yang memperberat rasa gatal. Pemberian minyak 
zaitun (Olive Oil) yang diberikan pada sore hari berpengaruh mengurangi pruritus dan memperbaiki kerusakan integritas kulit pada pasien DM, dikarenakan proses pelepasan hormon melatonin terjadi pada saat malam hari dan hormone ini merupakan salah satu proses pembentukan sel kulit (Hayati et al., 2020)

Tetapi pada dua pasien tidak terjadi perubahan skor pre dan post dalam penelitian ini, hal ini mungkin disebabkan karena lamanya terapi hemodialisis dan terbiasa mengalami gatal pada kulit. Lama menderita penyakit penyakit ginjal kronik dan terapi hemodialisa pada pasien ini ialah 8 tahun dan 6 tahun, sehingga dengan lamanya menderita PGK dan menjalani hemodialisis ini membuat persepsi pasien pada gatal menjadi biasa dan kurang berpengaruh akan terapi tambahan yang diberikan.

Selanjutnya masih ditemukan $21,7 \%$ (5 orang) mengalami pruritus pada skor 5 atau gatal sangat menganggu. Hal ini dapat disebabkan karena toksik uremia yang tinggi karena asupan makanan yang tidak dijaga dan kondisi kulit yang sering berkeringat sehingga pengeluaran toksik uremia lewat keringat dapat menyebabkan kulit lebih gatal. Oleh karena itu selain menjaga kelembaban kulit dengan menggunakan minyak zaitun pasien juga perlu menjaga asupan makanan untuk menjaga peningkatan toksik uremia. Selain itu pasien juga perlu menghindari suhu ruangan yang panas atau aktivitas berlebih yang menyebabkan pengeluaran keringat yang dapat memicu timbulnya gatal-gatal pada kulit.

\section{SIMPULAN DAN SARAN}

Berdasarkan penelitian, dapat disimpulkan ada pengaruh pemberian emoilen minyak zaitun terhadap skala pruritus pada pasien yang menjalani hemodialisis. Minyak zaitun dapat mengisi ruang keratin kulit sehingga melembabkan, mencegah kulit gatal, mengobati luka dan infeksi. Oleh karena itu perlu dilakukan terapi tambahan berupa penggunaan terapi topikal minyak zaitun untuk mengatasi pruritus pada pasien penyakit ginjal kronik.

\section{DAFTAR PUSTAKA}

Ariyani, H., Hilmawan, R. G., \& Baharudin, L. S. (2020). Effectiveness of Allium Sativum and Olive Oil in Overcoming Pruritus in Kidney Failure Patients at Hemodialysis Unit of Dr. Soekardjo Hospital, Tasikmalaya City. 26, 146-148. https:// doi.org/10.2991/ahsr.k.200523.036

Astuti, R, Husna, C. (2017). Skala Pruritus Pada Pasien Gagal Ginjal Kronik. Jurnal Ilmiah Mahasiswa Fakultas Keperawatan Universitas Syiah Kuala, 1-6.

Black, J.M., \& Hawks, J. . (2014). Keperawatan Medikal Bedah: Manajemen Klinis untuk Hasil yang Diharapkan. Jakarta: Salemba Medika, 2014.

Fajriyah, N. N., Andriani, A., Keperawatan, P., \& Zaitun, M. (2015). Efektivitas Minyak Zaitun untuk Pencegahan Kerusakan Kulit pada Pasien The effectiveness of Olive Oil for Skin Damage Prevention in Patients with Leprosy. Jurnal Ilmiah Kesehatan, VII(1).

Harlim, A., \& Yogyartono, P. (2012). Uremic Pruritus in Chronic Kidney Disease. Majalah Kedokteran FK UKI, XXVIII(2), 100-111.

Hayati, K., Mutiara, H. S., Agustina, D., Manalu, T. A., \& Sitepu, K. (2020). Pengaruh Minyak Zaitun (Olive Oil) Terhadap Kerusakan Integritas Kulit Pada Pasien Dm Tipe Ii Di Kecamatan Pagar Merbau. Jurnal Keperawatan Dan Fisioterapi (Jkf), 3(1), 6-12. https://doi. 
org/10.35451/jkf.v3i1.455

Ichihashi, M., Yanagi, H., Yoshimoto, S., Ando, H., Kunisada, M., \& Nishigori, C. (2018). Olive oil and skin anti-aging. 5(2), 8694. https://doi.org/10.24659/gsr.5.2

Kimata, N., Fuller, D. S., Saito, A., Akizawa, T., Fukuhara, S., Pisoni, R. L., Robinson, B. M., \& Akiba, T. (2014). Pruritus in hemodialysis patients: Results from the Japanese Dialysis Outcomes and Practice Patterns Study (JDOPPS). Hemodialysis International, 18(3), 657-667. https:// doi.org/10.1111/hdi.12158

Li, J., Guo, Q., Lin, J., Yi, C., Yang, X., \& Yu, $X$. (2015). Prevalence and associated factors of uraemic pruritus in continuous ambulatory peritoneal dialysis patients. Internal Medicine, 54(22), 2827-2833. https://doi.org/10.2169/ internalmedicine.54.4516

Lin, T. K., Zhong, L., \& Santiago, J. L. (2018). Anti-inflammatory and skin barrier repair effects of topical application of some plant oils. International Journal of Molecular Sciences, 19(1). https://doi.org/10.3390/ ijms 19010070

Lynde, C, John, K. (2012). Skin Manifestations of Kidney Disease Conditions Range From Benign. 15(2), 2012.

Mettang, T., \& Kremer, A. E. (2015). Uremic pruritus. Kidney International, 87(4), 685-691. https://doi.org/10.1038/ ki.2013.454

Notoatmodjo, S. (2013). Metodologi Penelitian Kesehatan. Jakarta : Rineka Cipta.

Panahi, Y., Dashti-Khavidaki, S., Farnood, F., Noshad, H., Lotfi, M., \& Gharekhani, A.
(2016). Therapeutic effects of omega-3 fatty acids on chronic kidney diseaseassociated pruritus: A literature review. Advanced Pharmaceutical Bulletin, 6(4), 509-514. https://doi.org/10.15171/ apb.2016.064

Pardede, S. O. (2016). Pruritus Uremik. Sari Pediatri, 11(5), 348. https://doi. org/10.14238/sp11.5.2010.348-54

Pele, M., \& Waluyo, A. (2019). Use of Olive Oil and Warm Water in Bathing Intervention in Preventing Risk of Skin Integrity Damage in Total Care Patients With Chronic Disease: A Case Study. Jurnal Pendidikan Keperawatan Indonesia, 5(1), 1-6. https://doi.org/10.17509/jpki. v5i1.13966

Registry, I. R. (2018). Indonesia Renal Registry 11th Report. Indonesia Renal Registry, 2018, 202018. https://www. indonesianrenalregistry.org/data/IRR 2018.pdf

Roswati, E. (2013). Pruritus pada Pasien Hemodialisis. Cdk, 40(4), 260-264.

Sebayang, S. M., \& Sembiring, E. (2020). Efektivitas Pemberian Minyak Zaitun Terhadap Ruam Popok Pada Balita Usia 0-36 Bulan. Indonesian Trust Health Journal, 3(1), 258-264. https://doi. org/10.37104/ithj.v3i1.44

Setianingsih, Y. A. (2017). Pengaruh Minyak Zaitun (Olive Oil) Terhadap Penyembuhan Ruam Popok Pada Bayi Usia 0-12 Bulan Di Desa Sukobanah Kabupaten Sampang Madura. Journal of Chemical Information and Modeling, 53(9), 1689-1699. 
